\title{
Re-Examining the Demand for Money in Asean-5 Countries
}

\author{
Hussin Abdullah \\ College of Arts and Sciences, Universiti Utara Malaysia, 06010 Sintok, Kedah, Malaysia \\ Tel: 60-4-928-3551 E-mail: ahussin@uum.edu.my \\ Jamal Ali \\ College of Arts and Sciences, Universiti Utara Malaysia, 06010 Sintok, Kedah, Malaysia \\ Tel: 60-4-928-6782Ｅ-mail: jamalali@uum.edu.my
}

Hylmee Matahir

Faculty of Business Management, Universiti Teknologi Mara (UITM), Kota Kinabalu Campus, Malaysia

Tel: 60-1-6680-6796 E-mail: hylme703@sabah.uitm.edu.my

\begin{abstract}
The objective of this study is to re-examine the demand for money in ASEAN-5 countries, namely Indonesia, Malaysia, the Philippines, Singapore, and Thailand using the autoregressive distributed lag (ARDL) approach to cointegration analysis. The empirical results show that there is a unique cointegrated and stable long-run relationship among broad monetary aggregate, income, interest rate, exchange rate, foreign interest rate, and inflation. We found that the income elasticity and the exchange rate coefficient are positive while the inflation elasticity is negative. This indicates that depreciation of domestic currency increases the demand for money, supporting the wealth effect argument and people prefer to substitute physical assets for money balances that support our theoretical expectation.
\end{abstract}

Keywords: ASEAN-5, ARDL, Cointegration, Demand for money

\section{Introduction}

Developing countries face a new challenge from the global financial crisis, which is rapidly becoming an unemployment crisis. The World Bank Group is helping with the financial rescue but believes that we must remain focused on rescuing the many millions of employees left behind. The Bank is calling for developed countries to pledge $0.7 \%$ of their stimulus packages, or as much as they can in additional money, to a global vulnerability fund to help developing countries, which cannot afford bailouts and deficits.

The financial turmoil is fast spreading, and the trickle-down effect can be felt in the rest of the world, including ASEAN economies. ASEAN economies also felt a setback in terms of losing investors' wealth. The stock markets across the region faced panic selling and reflected the sentiment of the falling global capital markets. These financial crises show a situation in which the supply of money is outpaced by the demand for money. This means that liquidity is quickly evaporated because available money is withdrawn from banks, forcing the banks either to sell other investments to make up for the shortfall or to collapse.

General uncertainty in the economy could have an impact on the quantity of money that economic agents are willing to hold. For example, an increase in interest rate risk, in the form of volatility, also increases the risk of bearing fixed-term interest-paying securities. Economic agents in this environment substitute these securities for more money. In the same vein, an increase in inflation uncertainty makes all nominal assets riskier, because their value in terms of goods and services becomes less predictable. Thus, in an uncertain inflationary environment, economic agents could shift out of nominal assets, including money, into tangible assets such as gold or commodities. Another influencing factor that might affect the quantity of money that agents are willing to hold is the uncertainty surrounding the stock market.

The role of monetary targets in the conduct of monetary policy has been reduced in recent years. Singapore, since the early 1980 s has focused primarily on managing the exchange rate as its principal monetary instrument. In Malaysia, the emphasis of the monetary policy shifted during the 1980s from M1 to M2, and then to M3 in recent years. The Bank of Thailand has shifted its monetary policy emphasis from M2 to commercial bank credit, 
the private sector and the domestic interest rate. Indonesia is continuing to set money and credit targets, and is conducting a reserve money programming exercise (Dekle and Pradhan, 1997).

Demand for money and its stability have received vast attention in the country specific time series studies. Developments in the unit roots, cointegration techniques and the financial reforms have stimulated further empirical work on this already well-researched relationship. It is now an almost stylized fact that the demand for narrow and broad money has become temporally unstable in the developed countries after continuing changes due to the financial reforms. Reforms have increased competition, created additional money substitutes, increased use of credits cards and electronic money transfers, increased liquidity of the time deposits and led to higher international capital mobility (Rao and Kumar, 2009).

Poole (1970) stated that the demand for money is stable, and central banks should use money supply as the monetary policy instrument. Interest rate used as the policy instrument will only accentuate instability. Therefore, it is important to know if the money-demand functions in the developing countries have become unstable. Stable money demand implies that using the rate of interest as the monetary policy instrument is inappropriate.

Other than that, there are considerably vast researches on the stability of demand function for money, such as that of Rao and Singh (2005), Takeshi and Hamori (2008), Hosein (2007), Bahmani-Oskooee and Yongqing Wang (2007), Tan (1997) and Valadkhani (2008). These studies generally estimate the stability of the money-demand function with different cointegration approaches.

In India, Rao and Singh (2005) conducted a research based on data from 1953 to 2002 and found that M1, which is defined as narrow money, was stable during that period. It also concluded, based on standard unit root and cointegration methodology, that income and interest elasticities of money demand are significant. Meanwhile, Takeshi and Hamori (2008) concluded in their study that M1 or M2 is good indicator in the purpose of managing the monetary policies in India instead of M3. Based on a set of data range from 1976 to 2000 annually, interest rate and output appear to be consistently significant with real money balances.

Another researcher had applied the ARDL method to investigate the cointegration among the variables which proposed by Pesaran and Shin (1995) and Pesaran et al. (2001). Bahmani-Oskooee and Yongqing Wang (2007) investigated the stability of the money-demand function in the Chinese economy by employing quarterly data from 1983I to 2002IV. They found that M2 should not be a targeting instrument for monetary policy since CUSUM and CUSUMSQ show that M2 is not stable compared to M1. A similar approach conducted by Hosein (2007) in Iranian money demand behaviour, found that M1 was stable based on the data studied. The paper also revealed that the demand for money has a stable relationship in the long-run with income, inflation and interest rate.

Tang (2007) estimated the long-run relationship between M2 balances and its determinant components such as real GDP, exchange rate, and inflation rate in ASEAN economies (including Malaysia, the Philippines, Thailand, Indonesia and Singapore) from 1960 to 2005. Individually, M2 balances in Malaysia, the Philippines and Singapore appeared to be cointegrated with real GDP, exchange rate and inflation. However, the other two countries showed no cointegration. The author proceeded with the ARDL test and found that, excluding Indonesia, the money-demand function in all member countries was stable in the short run.

Valadkhani (2008) investigated the long-run and the short-run relationship between money demand and its determinant variables among six Asian-Pacific countries. This study included effective exchange rate and US real interest rate to test currency substitution and the capital-mobility hypothesis. Based on the Engle-Granger two-step procedure (testing for long-run cointegration), cointegration existed between M2 and its determinants, and supports the expected sign of each individual variable. This means that all the determinants can change significantly if the monetary policy is in place. However, in the short-run, the ECM test showed that only income, inflation and interest rate have significant effects on the change in M2 suggesting that currency substitution and capital mobility are only valid in the long-run period.

This paper re-examines the extent that the financial market changes in the ASEAN-5 countries have affected the demand for money behavior and seeks to draw the implication for the monetary policy. We also attempt to assess whether demands for money equations are relatively stable and predictable and also whether they are an important prerequisite for operating a policy framework centered on monetary targets. Lastly, this paper aims to highlight the cointegrating properties of M1 and M2 monetary aggregates, income, inflation, foreign interest rate, exchange rate, and interest rate using the cointegrating technique known as the ARDL approach. The remainder of this paper is organized as follows: section (2) introduces the theoretical model and discusses the ARDL approach, section (3) displays the major results, and section (4) concludes. 


\section{Methodology and the Specification of Model}

According to Harb (2003) money demand is formulated as following:

$$
\mathrm{M}_{\mathrm{t}}=\mathrm{f}\left(\mathrm{S}_{\mathrm{t}}, \mathrm{O}_{\mathrm{t}}\right) \quad \mathrm{f}_{\mathrm{s}}^{\prime}>0, \mathrm{f}_{\mathrm{o}}^{\prime}<0
$$

where $\mathrm{M}_{t}$ is the quantity demanded of money, $\mathrm{S}_{t}$ is a scale variable and $\mathrm{O}_{t}$ is the opportunity cost of holding money. The variables used for the estimation of the money-demand function depend on the theoretical function of money. We estimate the following money-demand equation

$$
M_{t}=\beta_{0}+\beta_{1} Y_{t}+\beta_{2} R_{t}+\beta_{3} E R_{t}+\beta_{4} F R_{t}+\beta_{5} \pi_{t}+\varepsilon_{t}
$$

where the $i$ index refers to the given number of the panel. $M_{t}$ is the natural logarithm of the real monetary aggregate for country $i$. In our study, we used narrow money (M1) and board money (M2) as monetary aggregate. $Y_{t}$ is the logarithm of the real income as a scale variable, $R_{t}$ is local real interest rate, $E R_{t}$ is the real exchange rate per US dollar (a depreciation of the domestic currency or increase in $E R_{t}$ raises the value of the foreign assets in terms of domestic currency), $F R_{t}$ is foreign real interest rate and $\pi_{t}$ is rate of inflation. $\beta_{0}$, $\beta_{1, \ldots,}, \beta_{5}$ are the slopes to be estimated.

The six series in the model are expected to be non-stationary. Thus, we rewrite the previous equation as:

$$
\varepsilon_{t}=M_{t}-\beta_{0}-\beta_{1} Y_{t}-\beta_{2} R_{t}-\beta_{3} E R_{t}-\beta_{4} \mathrm{FR}_{\mathrm{t}}-\beta_{5} \pi_{t}
$$

\section{The ARDL Approach}

Various factors are considered as determinants of the demand for money. The general agreement in the literature is that the demand for money equation should contain a scale variable to the level of transactions in the economy and a variable representing the opportunity cost of holding money. In the context of an open economy, variables such as exchange rate, foreign interest rate or interest rate differentials reflecting the relative returns of foreign money vis-à-vis domestic money can be included in the demand for money equation to reflect the impact of currency depreciation on domestic money demand. Furthermore, due to the absence of well-developed financial markets in most developing countries, the inflation rate is used as a proxy for the opportunity cost. In the Bahmani-Oskooee (1996) and the Bahmani-Oskooee and Rehman (2005) studies it is assumed that the money-demand function takes the following form:

$$
\ln M_{t}=\beta_{0}+\beta_{1} \ln Y_{t}+\beta_{2} R_{t}+\beta_{3} \ln E R_{t}+\beta_{4} F R+\beta_{5} \pi_{t}+\mu_{t}
$$

According to Arango and Nadiri (1981) and Bahmani-Oskooee and Pourheydarian (1990), an estimate of $\beta_{1}$ is expected to be positive, an estimate of $\beta_{2}$ to $\beta_{4}$ could be negative or positive. Estimation of $\beta_{5}$ is expected to be negative.

In applying the cointegration technique, we need to determine the order of the cointegration of each variable. However, as noted in the literature, depending on the power of the unit root tests, different tests yield different results. In view of this problem, Pesaran and Shin (1995) and Pesaran et al. (2001) introduced a new method of testing for cointegration. The approach is known as the autoregressive distributed lag (ARDL) approach. This method has the advantage of avoiding the classification of variables into $I(1)$ or $\mathrm{I}(0)$ and unlike standard cointegration tests, there is no need for unit root pre-testing. However, the ARDL approach is very suitable for our formulation of the demand for money because we may have a stationary variable such as inflation rate along with non-stationary variables such as money or income. The error-correction version of the ARDL model pertaining to the variables in Equation 4 is as follows: 


$$
\begin{aligned}
\Delta \ln M_{t}= & \beta_{0}+\sum_{i=1}^{n} \beta_{l i} \Delta M_{t-1}+\sum_{i=0}^{n} \beta_{2 i} \Delta \ln Y_{t-1}+\sum_{i=0}^{n} \beta_{3 i} \Delta R_{t-1}+\sum_{i=0}^{n} \beta_{4 i} \Delta E R_{4 t}+\sum_{i=0}^{n} \beta_{5 i} \Delta \ln F R_{t-1} \\
& +\sum_{i=0}^{n} \beta_{6 i} \Delta \pi_{i=0}+\sum_{i=0}^{n} \gamma_{1} \ln M_{t-1}+\gamma_{2} \ln Y_{t-1}+\gamma_{3} R_{t-1}+\gamma_{4} E R_{t-1}+\gamma_{5} \ln F R_{t-1}+u_{t}
\end{aligned}
$$

The null of no cointegration defined by $H_{0}: \gamma_{1}=\gamma_{2}=\gamma_{3}=\gamma_{4}=\gamma_{5}=\gamma_{6}=0$ is tested against the alternative of $H_{1}: \gamma_{1} \neq \gamma_{2} \neq \gamma_{3} \neq \gamma_{4} \neq \gamma_{5} \neq \gamma_{6} \neq 0$, by means of the familiar F-test.

However, the asymptotic distribution of this F-statistics is non-standard irrespective of whether the variables are $I(0)$ or $I(1)$. Pesaran et al. (2001) tabulated two sets of appropriate critical values. One set assumes all variables are $I(1)$ and another assumes that they are all $\mathrm{I}(0)$. This provides a band covering all possible classifications of the variables into $I(1)$ and $I(0)$ or even fractionally integrated. If the calculated F-statistics lies above the upper level of the band, the null is rejected, indicating cointegration. If the calculated F-statistics falls below the lower level of the band, the null cannot be rejected, supporting lack of cointegration. If, however, it falls within the band, the result is inconclusive.

\section{Empirical Results}

To ensure there are long-term relationships among the variables in the models, the Augmented Dickey-Fuller (ADF) test or stationarity data is carried out for all variables in ASEAN-5 countries. If the variables found in Equation (2) have the same level of stationarity, that is $I(1)$, then long-run relationship or cointegration may exist between variables in the equation. The existence of cointegration means that the result of the regression in Equation (2) is not a spurious regression and it forms a similar wave in the long term.

Table 1 reports the statistics for unit root for each series in the time series. The empirical results show that we cannot reject the existence of unit root in almost all variables at a significant statistical conventional level in both the constant and the constant plus trend and the inflation $(\pi)$ in the constant plus trend. This means that inflation $(\pi)$ is stationary in both levels. The ADF test was carried out again in the first difference approach and the result is reported in Table 1 . This result demonstrates that almost all the series are stationary at $1 \%, 5 \%$, and $10 \%$ significant levels $I(1)$.

It is clear from the empirical results in Table 1, that under these circumstances and especially when we face mixed results, applying the ARDL bounds approach is the efficient way of determining the long-run relationships among the variables under investigation.

\section{Cointegration Tests}

The cointegration test in the bounds' framework involves the comparison of the $F$-statistics against the critical values, which are generated for specific sample sizes (Narayan, 2005). The bounds tests for M1 and M2 for ASEAN-5 countries are presented in Table 2 .

Using the asymptotic critical value computed by Narayan (2005), we find that all the test statistics are significant at the 1\% level (Indonesia, Malaysia, and Thailand) and the 5\% level (the Philippines and Singapore) for M2. But for M1 we find that only Indonesia, the Philippines and Thailand have the test statistically significant at the $1 \%$ and the $5 \%$ levels respectively. These results lead us to reject the null hypothesis of no cointegration, regardless of whether the variables are $I(1)$ or $I(0)$ or a mix of both. These tests also indicate the presence of valid long-run relationships between the independent variables and the dependent variable (M1 and M2) for the ASEAN-5 countries at the calculated $F$-statistics of 9.965 (Indonesia), 7.068 (the Philippines) and 5.032 (Thailand) for M1 which exceed the upper critical value at the $1 \%$ and the 5\% significant levels respectively. M1 also shows that the calculated $F$-statistics are 0.613 (Malaysia) and 0.850 (Singapore) which are not significant at any level, indicating that there are no long-run relationships between the independent variables and the dependent variable. M2 shows that the calculated $F$-statistic are 8.550 (Indonesia), 9.934 (Malaysia), 4.070 (the Philippines), 6.726 (Singapore), 9.5548 (Thailand) and 6.726 (Singapore) which exceed the upper critical value at the $1 \%$ and the $5 \%$ significant levels respectively. These indicate that there are long-run relationships between the independent variables and the dependent variable.

To ascertain the goodness of the ARDL model, the diagnostic test and the stability test were conducted. Table 3 shows that M1 and M2 for the ASEAN-5 countries generally pass the the Breusch-Godfrey Serial Correlation LM test, Jacque-Bera normality test, Ramsey RESET stability test and ARCH test in the first stage. These tests show that there is no evidence of autocorrelation and that the models pass the tests for normality and thus proving that the error is normally distributed. 


\section{Long-run and Short-run Estimations}

In the first step of the analysis of the ARDL, the existence of the long-run coefficients of Equation (2) is estimated and the results are reported in Table 4. As discussed earlier, one of the important issues in applying the ARDL is the choice of the order of the distributed lag function. In order to select the best performing ARDL model, the significance of the resulting ARDL-VECM parameters, the Schwarz Bayesian Criterion (SBC) are preferred to other model specification criteria because it tends to define more parsimonious specifications: the small data sample in the current study underlies this preference (Pesaran and Smith, 1998).

As presented in Table 4, the long-run coefficients for Equation (2) follow a similar pattern. The results show that for M1 monetary aggregate, income $(Y t)$ variable is not significant for all ASEAN-5 countries. However, we found that income $(Y t)$ is negatively related to M2 monetary aggregate in the long-run for Indonesia, Malaysia, the Philippines and Thailand, and positively related to M2 for Singapore. This variable is statistically significant at the $10 \%, 5 \%$ and $1 \%$ levels respectively. In short run income $(Y t)$ has positively related to M1 monetary aggregate only for Indonesia and Thailand and statistically significant at the $1 \%$ and the $10 \%$ levels respectively. However, for M2 monetary aggregate we found that income $(Y t)$ is negatively related for the Indonesia, the Philippines and Singapore in the short-run and is statistically significant at the $1 \%$ level, whereas, Thailand has a positive relationship between income and M2 in the short-run and is statistically significant at the $5 \%$ level.

In Table 4, the interest rate has negative and positive relationships to monetary aggregate (M1) in the long-run for Indonesia and the Philippines and the variable is statistically significant at the 5\% level. However, this variable is not significant in Malaysia, Singapore and Thailand. For M2 monetary aggregate, there is a positive relationship with interest rate for Indonesia, Malaysia, and Singapore and is statistically significant at the $1 \%$ and the $10 \%$ levels respectively. We also found that in the short-run the interest rate has negative and positive relationships with monetary aggregate (M1) in the long-run for Indonesia and Malaysia and the variable is statistically significant at the 5\% level, but for M2 monetary aggregate, there is a positive relationship with interest rate for Indonesia and is statistically significant at the 5\% level. In Malaysia and Thailand, there is a negative relationship between interest rate and M2 monetary aggregate and is statistically significant at the 5\% level.

The results show that exchange rate is negatively related to M1 monetary aggregate in the long-run only for Malaysia which is statistically significant at the $5 \%$ level. However, exchange rate is negatively related to M2 monetary aggregate in the long-run for Indonesia and the Philippines and is statistically significant at the 1\% level. On the other hand, exchange rate in Malaysia and Thailand has a positive relationship to M2, and this variable is statistically significant at the $1 \%$ level. In the short-run, exchange rate is positively related to M1 monetary aggregate only for Indonesia and is statistically significant at the 1\% level. However, for M2 monetary aggregate we found that exchange rate is negatively related for the Philippines and Singapore in the short run and is statistically significant at the $1 \%$ level.

Foreign interest rate, like exchange rate, is positively related to M1 monetary aggregate in the long-run only for Indonesia at the 5\% significant level. For M2 monetary aggregate, there is negative relationship with foreign interest rate for Indonesia, and Singapore and is statistically significant at the 5\% and the $10 \%$ levels. On the other hand, in the Philippines there is positive relationship between M2 and foreign interest rate. We also found that in the short-run foreign interest rate is positively related to monetary aggregate (M1) in the long-run for Indonesia, Malaysia and Thailand. This variable is statistically significant at the $5 \%$ and the $10 \%$ levels. But for M2 monetary aggregate, there is negative relationship with interest rate for Indonesia and Malaysia at the statistically significant 5\% level. In Thailand, there is positive relationship between foreign interest rate and M2 monetary aggregate and is statistically significant at the $1 \%$ level.

Inflation is strongly negatively related to M1 in the long-run for Malaysia and the Philippines and is statistically significant at the $5 \%$ and the $1 \%$ levels. The results also show that for M2 monetary aggregate, the inflation variable is negatively related for Indonesia and is statistically significant at the $1 \%$ level. However, we found that inflation is positively related to M2 monetary aggregate in the long-run for the Philippines and Thailand. This variable is statistically significant at the $1 \%$ and the $10 \%$ levels. In the short-run, inflation is positively related to M1 monetary aggregate only for Indonesia and Malaysia and is statistically significant at the $1 \%$ level. However, for M2 monetary aggregate, we found that inflation is negatively related for Malaysia but positively related for the Philippines and Thailand and is statistically significant at the $1 \%$ and the $10 \%$ levels.

As discussed earlier, the error correction term indicates the speed of the adjustment which restores equilibrium in the dynamic model. The ECM coefficient shows how quickly variables return to equilibrium and it should have a statistically significant coefficient with a negative sign. Bannerjee et. al. (1998) hold that a highly significant 
error correction term is a further proof of the existence of a stable long-run relationship. Therefore, having determined the long-run coefficients for each selected ARDL model, we derived the estimates for the error correction models.

The results are displayed in Table 4. The one-lagged error correction terms (ECM) in M1 and M2 for ASEAN-5 countries are found to have the expected negative sign and are highly statistically significant at the $1 \%, 5 \%$, and the $10 \%$ levels. This confirms once again, the existence of cointegrated relationships among the variables of M1 and M2. The coefficients of $\operatorname{ECM}(-1)$ are -0.549 (Indonesia), -0.447 (Malaysia), -0.842 (The Philippines), -0.839 (Singapore), and -0.968 (Thailand) for M1. For M2, we found that the coefficients of ECM(-1) are -0.818 (Indonesia), -0.740 (Malaysia), -0.525 (The Philippines), -0.973 (Singapore), and -0.569 (Thailand). These imply that deviations from the long-run in M1 and M2 are corrected by the $44 \%$ to the $97 \%$ over the following year. This means that the adjustment takes place relatively. For example, the speed of adjustment is relatively high. We conclude that Table 4 contains the final estimation results of the error-correction model based on the ARDL approach. These results in M1 and M2 for ASEAN-5 countries give us some intuitions on the order of magnitude of the impacts of income, real interest rate, real exchange rate, foreign real interest rate and the rate of inflation on monetary aggregate $\mathrm{M} 1$ and monetary aggregate $\mathrm{M} 2$.

\section{Conclusion}

In this paper we have shown that the variables in the demand for money in five Southeast Asian countries are non-stationary in their levels in the time series. The existence of a valid long-run money-demand function is still important for the conduct of a monetary policy. The ADF test for unit roots supports the view that all the variables appearing on a standard money-demand function are $I(1)$. It is clear from the empirical result in Table 1 , that under these circumstances and especially when we face mixed results, applying the ARDL bounds approach is the efficient way of determining the long-run relationships among the variables under investigation. We found that M1 for Malaysia and Singapore are not significant at any level, indicating that there are no long-run relationships between the independent variables and dependent variable. On the other hand, M2 for all ASEAN5 countries exceed the upper critical value at the $1 \%$ and the $5 \%$ significant levels. These indicate that there are long-run relationships between the independent variables and the dependent variable.

These stationary tests show that a long-run relationship exists between the dependent and the independent variables. We proceeded to the next step with the ARDL test to verify the cointegration hypothesis among the variables of the money-demand function. We estimated the cointegration using the ARDL approach developed by Pesaran and Shin (1995) and Pesaran et al. (2001). In the ADF test, monetary aggregate M2 shows very good performance at constant and constant plus time trend. This means that the real M2 is a predictable monetary aggregate compared to monetary aggregate M1. In order to identify a long-run stable money-demand function for M1 and M2 for individual countries, we used the ARDL test and the results showed that real income affects money demand for monetary aggregate M2 for all ASEAN-5 countries.

The expected rate of inflation is usually the only variable used as the opportunity cost of holding money. From our research in the five ASEAN countries, we found that Malaysia and Singapore had a strong incentive for persons to switch out of money and into real assets when there are strong inflationary expectations. This rate of inflation is statistically significant in explaining changes in the demand for money. Other countries showed that there were positive relationships between inflation expectation and monetary aggregate $\mathrm{M} 2$ in the long-run. The estimated coefficient for the interest rate spread in this model was highly significant and had consistent signs for Indonesia, Malaysia, Singapore and Thailand. The estimated coefficient for exchange rate was highly significant with monetary aggregate M1 and M2 for Indonesia, the Philippines, Malaysia and Singapore.

The ECM of money demand is appropriate and it provides the basic structure to study the properties of money demand and to make forecasts. Finally from the monetary policy perspective, a monetary-targeting regime is feasible in the ASEAN-5 countries whereas an exchange-rate targeting regime might have an adverse impact on price stability, investment and growth. Given the higher inflation elasticity of money demand, it can be concluded that the monetary policy in the ASEAN-5 countries must target inflation rate and simultaneously monitor the impacts of changes in the commodity prices, monetary aggregates and growth on inflation rate.

Based on the results, we conclude that a broad definition of money M2 is a better measure than a narrow definition of money M1 in considering the long-run economic impacts of changes in monetary policy in the ASEAN-5 countries. There is a unique cointegrated and stable long-run relationship among broad monetary aggregate, income, interest rate, exchange rate, foreign interest rate, and inflation. Our findings on the income elasticity and the exchange rate coefficient are positive while the inflation elasticity is negative. This indicates that depreciation of domestic currency increases the demand for money, supporting the wealth-effect argument 
and people prefer to substitute physical assets for money balances that support our theoretical expectation. Even though our results are fairly significant and imply a stable demand for money in the five ASEAN countries, they have some limitations. We do not have better methods to decide endogenous in the time series data. We hope that our paper will provide incentives for further work to improve time series data estimation methods.

\section{References}

Arango, S. \& Nadiri, M. I. (1981). Demand for money in open economy. Journal of Monetary Economics, 7 , 69-83.

Bahmani-Oskooee, M, and Pourheydarian, M. (1990). Exchange rate sensitivity of demand for money and effectiveness of fiscal and monetary policies. Applied Economics, 22, 917-925.

Bahmani-Oskooee, M. \& Rehman, H. (2005). Stability of the money demand function in Asian developing countries. Applied Economics, 37, 773-792.

Bahmani-Oskooee, M. (1996). The black market exchange rate and demand for money in Iran. Journal of Macroeconomics, 18, 171-176.

Bahmani-Oskooee. M. \& Yongqing W. (2007). How stable is the demand for money in China? Journal of Economic Development, 1(32).

Banerjee, A., Dolado, J. J. \& Mestre, R. (1998). Error correction mechanism tests for cointegration in a single-equation framework, Journal of Time-series Analysis, 19, 267-83.

Dekle, R. \& Pradhan, M. (1997). Financial liberalization and money demand in ASEAN Countries: Implication for monetary policy. IMF, Working Paper WP/97/36, IMF. Washington D.C.

Harb, N. (2003). Money demand function: Heterogeneous panel application. Unpublished paper, Economics Department, UAE University.

Hosein, S.R. (2007). Demand for money in Iran: An ARDL approach. MPRA Paper No. 8224.

Narayan, P.K.. (2005). The saving and investment nexus for China: Evidence from cointegration tests. Applied Economics, 37, 1979-1990.

Pesaran, M. H. \& Pesaran, B. (1997). Working with Microfit 4.0: Interactive econometric analysis. Oxford, Oxford University Press.

Pesaran, M. H. \& Y. Shin. (1995). An autoregressive distributed lag modelling approach to Cointegration analysis. DAE Working Paper No. 9514, Department of Applied Economics (Cambridge: Cambridge University).

Pesaran, M. H., Shin, Y. \& Smith, R.J. (2001). Bounds testing approaches to the analysis of level relationships. Journal of Applied Econometrics, 16(3): 289-326.

Poole, W. (1970). The optimal choice of monetary policy instruments in a simple macro model. Quarterly Journal of Economics, 192-216.

Rao, B.B. \& Kumar, S. (2009). A panel data approach to the demand for money and the effects of financial reforms in the Asian Countries. Economic Modelling, 26, 1013-1017.

Rao, B.B. \& Singh, R. (2005). Demand for money in India: 1953-2003. Applied Economics, 38, 1319-1326.

Takeshi, I. \& Shigeyuki, H. (2008). An empirical analysis of money demand function in India. Institute of Developing Economies, IDE Discussion Paper No. 166.

Tan, E. C. (1997). Money demand amid financial sector developments in Malaysia. Applied Economics, 29, 1201-1215.

Tang, T. C. (2007). Money-demand function for Southeast Asian countries: An empirical view from expenditure components. Journal of Economics Studies, Vol. 34(6), 476-496.

Valadkhani, A. (2008). Long-run and short-run determinants of the demand for money in the Asian-Pacific countries: An empirical panel investigation. Journal of Economics and Finance, 9-1, 77-90. 
Table 1. The Augmented Dickey-Fuller (ADF) test for a unit root; test for $I(0)$ and $I(1)$

\begin{tabular}{|c|c|c|c|c|c|}
\hline & & & & & nce \\
\hline & & Constant & Constant + Trend & Constant & Constant + Trend \\
\hline & $\ln M l_{t}$ & -1.872 & -2.750 & $-3.178 * *$ & $-3.521 * *$ \\
\hline$\Xi$ & $\ln M 2_{t}$ & -0.278 & -1.380 & $-7.654^{*}$ & $-7.509 *$ \\
\hline$\sqrt{G}$ & $\ln Y_{t}$ & -1.915 & -1.447 & $-3.911^{* *}$ & $-4.111 * *$ \\
\hline $\bar{b}$ & $R_{t}$ & -1.570 & -1.341 & $-4.418 * *$ & $-4.415^{* *}$ \\
\hline ○ & $E_{t}$ & 0.353 & -2.616 & $-4.204 * *$ & $-4.102^{* *}$ \\
\hline & $\ln F R_{t}$ & 0.263 & -1.01989 & $-4.287 * *$ & $-4.588 * *$ \\
\hline & $\Pi_{t}$ & $-4.809 * *$ & $-4.735 * *$ & $-6.642 *$ & $-6.510^{*}$ \\
\hline & $\ln M l_{t}$ & -1.645 & -1.685 & $-5.038 *$ & $-5.363^{*}$ \\
\hline$\leq$ & $\ln M 2_{t}$ & -2.100 & -2.240 & $-7.717^{*}$ & $-7.826 *$ \\
\hline$\overline{2}$ & $\ln Y_{t}$ & -1.097 & -2.032 & $-5.206^{*}$ & $-5.106^{*}$ \\
\hline 3 & $R_{t}$ & -1.664 & -2.064 & $-4.258 * *$ & $-4.248 * *$ \\
\hline$z$ & $E_{t}$ & -0.817 & -2.380 & $-5.911 *$ & $-5.975^{*}$ \\
\hline & $\ln F R_{t}$ & -1.139 & -1.189 & $-4.228 * *$ & $-4.495^{* *}$ \\
\hline & $\Pi_{t}$ & $-2.859 * * *$ & $-2.857^{* * *}$ & $-7.000 *$ & $-6.883 *$ \\
\hline & $\ln M l_{t}$ & -1.957 & -1.019 & $-5.477^{*}$ & $-6.913 *$ \\
\hline 积 & $\ln M 2_{t}$ & -2.172 & -2.327 & $-3.224 * *$ & $-4.596 * *$ \\
\hline$\frac{2}{2}$ & $\ln Y_{t}$ & -1.039 & -1.779 & -2.751 & $-4.466 * *$ \\
\hline$\frac{1}{2}$ & $R_{t}$ & -0.103 & -1.688 & -1.732 & $-3.779 * * *$ \\
\hline$\Xi$ & $E_{t}$ & -0.522 & -2.098 & $-3.548 * *$ & $-3.470 * *$ \\
\hline$\frac{1}{2}$ & $\ln F R_{t}$ & 0.252 & -2.037 & $-3.211^{* * *}$ & $-4.497 * *$ \\
\hline & $\Pi_{t}$ & $-4.586^{* *}$ & $-5.682 *$ & $-7.606^{*}$ & $-7.452^{*}$ \\
\hline & $\ln M l_{t}$ & -1.058 & -2.074 & $-2.810^{* * *}$ & $-4.384 * *$ \\
\hline 됟 & $\ln M 2_{t}$ & -0.590 & -2.023 & $-3.000 * *$ & $-4.680 * *$ \\
\hline$\overline{2}$ & $\ln Y_{t}$ & -0.824 & -2.533 & $-4.870 * *$ & $-4.724 * *$ \\
\hline 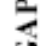 & $R_{t}$ & 0.577 & -1.218 & $-4.337^{* *}$ & $-4.851 * *$ \\
\hline 3 & $E_{t}$ & -1.746 & -2.070 & $-3.619^{* *}$ & $-3.816^{* *}$ \\
\hline$\frac{5}{n}$ & $\ln F R_{t}$ & -2.267 & -1.762 & $-3.210^{* *}$ & $-5.127^{*}$ \\
\hline & $\Pi_{t}$ & $-3.297 * * *$ & $-3.901^{* * *}$ & $-7.323^{*}$ & $-7.224^{*}$ \\
\hline & $\ln M 1_{t}$ & -1.909 & -1.378 & $-2.950^{* * *}$ & $-3.331 * * *$ \\
\hline 0 & $\ln M 2_{t}$ & -1.378 & -0.842 & $-6.185^{*}$ & $-4.681 * *$ \\
\hline Z & $\ln Y_{t}$ & -2.011 & -2.009 & $-2.878^{* * *}$ & $-3.075^{* *}$ \\
\hline$\exists$ & $R_{t}$ & -1.337 & -0.058 & $-3.882 * *$ & $-4.721 * *$ \\
\hline$\Xi$ & $E_{t}$ & -0.789 & -1.825 & $-4.907 * *$ & $-4.814^{* *}$ \\
\hline E & $\ln F R_{t}$ & -1.378 & -1.774 & $-3.700^{* * *}$ & $-4.239 * *$ \\
\hline & $\Pi_{t}$ & $-3.057 * * *$ & $-3.387 * * *$ & $-7.334^{*}$ & $-7.208^{*}$ \\
\hline
\end{tabular}

Note: ${ }^{* * *},{ }^{* *}, *$ cannot reject the null of non-stationarity at the $10 \%, 5 \%$, and $1 \%$ levels. 
Table 2. Bounds Test for the existence of a level relationship

\begin{tabular}{lc|c}
\hline COUNTRY & $M 1$ & $M 2$ \\
\hline INDONESIA & $9.965^{*}$ & $8.550^{*}$ \\
MALAYSIA & 0.613 & $9.934^{*}$ \\
PHILIPPINES & $7.068^{*}$ & $4.070^{* *}$ \\
SINGAPORE & 0.850 & $6.726^{* *}$ \\
THAILAND & $5.032^{* *}$ & $9.554^{*}$ \\
\hline & & CRITICAL VALUE \\
\cline { 2 - 3 } & LOWER & UPPER \\
$1 \%$ significance level & 4.537 & 6.370 \\
$5 \%$ significance level & 3.125 & 4.608
\end{tabular}

Note: The critical values are taken from Narayan (2005), ${ }^{*}, * *$ and $* * *$ denote significance at the $1 \%, 5 \%$ and $10 \%$ levels.

Table 3. Diagnostic Checking

\begin{tabular}{|c|c|c|c|c|c|c|}
\hline & \multicolumn{3}{|c|}{$\ln M 1_{t}$} & \multicolumn{3}{|c|}{$\ln M 2_{t}$} \\
\hline & $\begin{array}{l}\text { Autocorrelation } \\
\text { (Breusch-Godfrey } \\
\text { Serial Correlation } \\
\text { LM Test) }\end{array}$ & $\begin{array}{l}\text { Jacque_Bera } \\
\text { Normality Test }\end{array}$ & $\begin{array}{l}\text { Ramsey } \\
\text { RESET } \\
\text { Stability } \\
\text { Test }\end{array}$ & $\begin{array}{l}\text { Autocorrelation } \\
\text { (Breusch-Godfrey } \\
\text { Serial Correlation } \\
\text { LM Test) }\end{array}$ & $\begin{array}{l}\text { Jacque_Bera } \\
\text { Normality Test }\end{array}$ & $\begin{array}{l}\text { Ramsey } \\
\text { RESET } \\
\text { Stability } \\
\text { Test }\end{array}$ \\
\hline & F-Statistic & $\chi^{2}(2)$ & F-Statistic & F-Statistic & $\chi^{2}(2)$ & F-Statistic \\
\hline Indonesia & $\begin{array}{r}1.528 \\
(0.237)\end{array}$ & $\begin{array}{r}2.802 \\
(0.106)\end{array}$ & $\begin{array}{r}1.346 \\
(0.310)\end{array}$ & $\begin{array}{r}1.863 \\
(0.190)\end{array}$ & $\begin{array}{r}0.032 \\
(0.858)\end{array}$ & $\begin{array}{r}0.078 \\
(0.788)\end{array}$ \\
\hline Malaysia & $\begin{array}{r}0.752 \\
(0.411)\end{array}$ & $\begin{array}{r}0.071 \\
(0.796)\end{array}$ & $\begin{array}{r}0.042 \\
(0.838)\end{array}$ & $\begin{array}{r}1.817 \\
(0.211)\end{array}$ & $\begin{array}{r}1.359 \\
(0.254)\end{array}$ & $\begin{array}{r}0.3548 \\
(0.566)\end{array}$ \\
\hline Philippines & $\begin{array}{r}1.394 \\
(0.216)\end{array}$ & $\begin{array}{r}1.883 \\
(0.152)\end{array}$ & $\begin{array}{r}1.205 \\
(0.282)\end{array}$ & $\begin{array}{r}0.503 \\
(0.363)\end{array}$ & $\begin{array}{r}0.488 \\
(0.502)\end{array}$ & $\begin{array}{r}0.355 \\
(0.556)\end{array}$ \\
\hline Singapore & $\begin{array}{r}2.928 \\
(0.121)\end{array}$ & $\begin{array}{r}0.138 \\
(0.718)\end{array}$ & $\begin{array}{r}0.550 \\
(0.465)\end{array}$ & $\begin{array}{r}0.084 \\
(0.776)\end{array}$ & $\begin{array}{r}0.109 \\
(0.745)\end{array}$ & $\begin{array}{r}0.036 \\
(0.849)\end{array}$ \\
\hline Thailand & $\begin{array}{r}0.052 \\
(0.316)\end{array}$ & $\begin{array}{r}0.098 \\
(0.774)\end{array}$ & $\begin{array}{r}0.008 \\
(0.926)\end{array}$ & $\begin{array}{r}2.874 \\
(0.134)\end{array}$ & $\begin{array}{r}1.444 \\
(0.123)\end{array}$ & $\begin{array}{r}0.637 \\
(0.432)\end{array}$ \\
\hline
\end{tabular}

Note: Number of fitted terms for Ramsey RESET is 2 


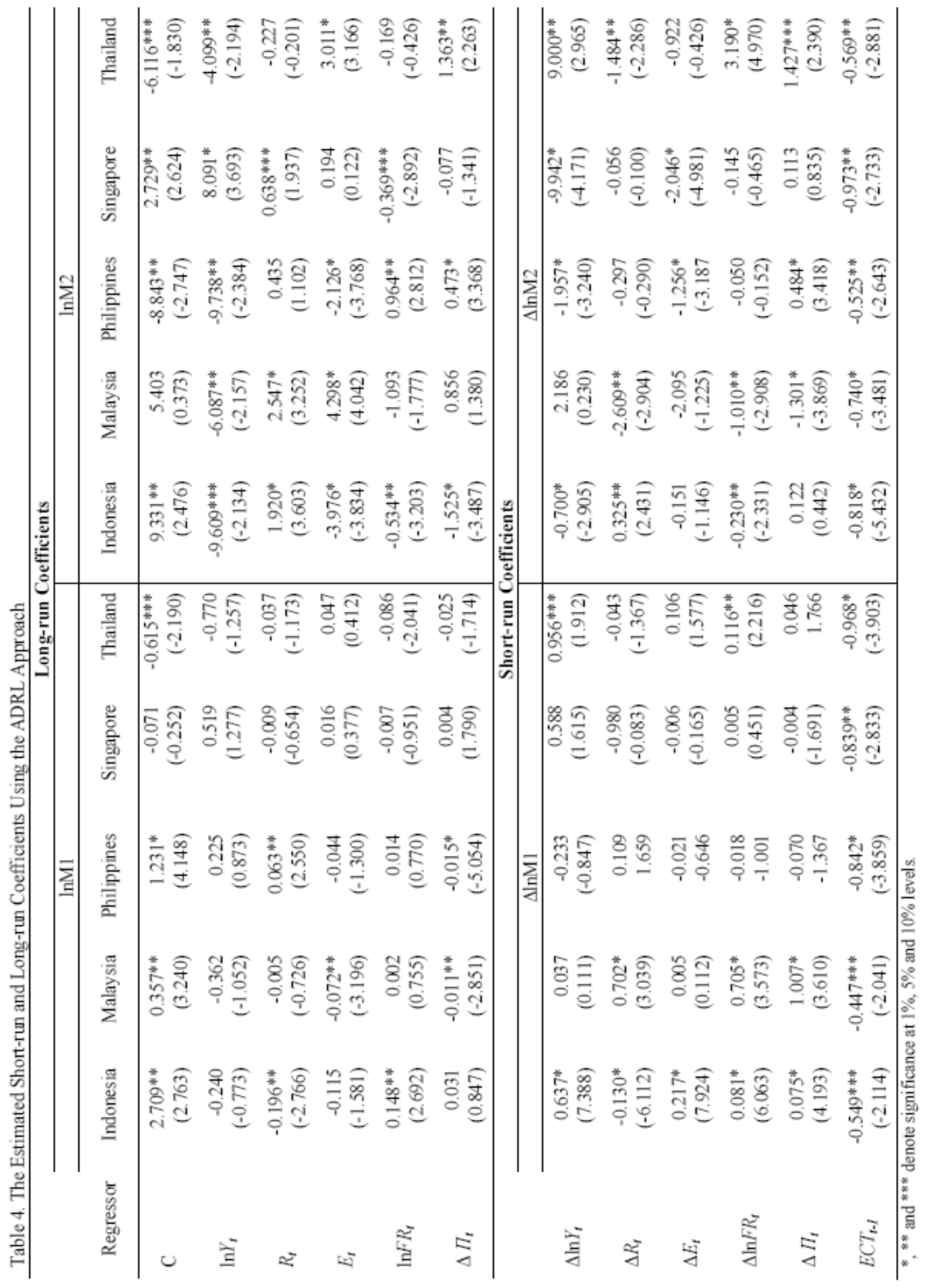

